\title{
Discovering and Reading the American Woman
}

\author{
Barbara Ozieblo Rajkowska \\ Universidad de Málaga
}

\begin{abstract}
In this paper, I examine the forces at work in the formation of the canon of American Literature in the early years of this century; the white anglo-saxon protestant male ethic dominant in other spheres prevailed in literature and thus women and other minority writers were excluded. The feminist movement of the last two decades has contributed to the revision of the canon, and many writers of merit have been recovered, including Susan Glaspell. Glaspell (1876-1848) was, with Eugene O'Neill, the principal playwright to work for the Provincetown Players; she was also a renowned novelist. In this paper, I offer a brief look at The Verge, a play acclaimed by feminists of her time.
\end{abstract}

The content of American Studies during the last twenty years has changed enormously: we no longer bow to Perry Miller and F. O. Mathiessen as the creators of the canon of American literature, and the texts of "minority" groups have rightfully decentred the long revered classics. I place the word "minority" in inverted commas quite deliberately: the largest group of writers to have achieved a measure of recognition during these two decades could never be considered a minority group. Women account for more than half the population of the world, and we are painfully aware of how our voices have been stifled by patriarchy. According to Tillie Olsen's historical study, Silences, the ration of known women to men writers is one-to-twelve, and many women -although acknowledged by their contemporaries- later suffered a "peculiar eclipsing" in favour of their male colleagues. ${ }^{1}$ While Nathaniel Hawthorne and Herman Melville -not overly popular in their day- have been the object of countless dissertations, Rebeca Harding Davis and Harriet Beecher Stowe, whose writings successfully supplemented their husbands' meagre incomes, passed into oblivion.

Recent studies have attempted to dis-cover what the institutionalizing of American Studies contrived to cover up, and slowly -in America at least- forgotten writers have been suffered to take their places in the literary canon. Here the process is much slower, but it has been initiated, and I hope this gathering will do something towards furthering it. We will be talking about women who have been rejected and ignored, and about the consequences of this process to our knowledge of the reality of the world we are studying. Thus our aim is not only to discover forgotter authors but also to revise our conceptions of their work and of their times. The world of Faulkner's novels was nor that of Tillie Olsen's, nor was it that of Nella Larsen, yet they wrote at the same time and were all Americans. ${ }^{2}$ 
Feminist literary criticism has given us the tools we need to examine the texts of all non-canonical writers and to work for their reinstatement. It has also made apparent the relative failure of previous women's movements; our feminist forbears forged the victories of abolition and suffrage but there was little sense of continuity between the activism of the mid-nineteenth century and the passing of the nineteenth amendment which gave women the vote. Each time women were deceived into believing that the battle had been won; many lacked confidence in the possibility, and even the desirability, of further achievement, and the Depressions of the $1870 \mathrm{~s}$ and 1929 thwarted those who wished to struggle on. The importance of continuity, of a conscious tradition, was pointed out by Virginia Woolf in England and picked up by the pioneers of the new feminism in America. These critics were devoted to the rediscovery of women's texts and to their reinterpretation. Re-vision -to use the term coined by Adrienne Rich- was marked by a lack of theory and a reliance on private experience which generated immense enthusiasm for the task as well as confidence in the results. Rich by no means exaggerated the case when, in the late seventies, she considered it to be "an act of survival." Nor did she over-estimate the power of literature when she stated:

A radical critique of literature, feminist in its impulse, would take the work first of all as a clue to how we live, how we have been living, how we have been led to imagine ourselves, how our language has trapped as well as liberated us, how the very act of naming has been till now a male prerogative, and how we can begin to see and name -and therefore live- afresh.

Rich's definition of literature, implicit in the words I have quoted, allows us to understand just how important the formation of a literary canon is -since it not only reflects but may also shape social reality. A lot of work has been done in this field in America; perhaps the clearest account of how the American literary canon of the sixties came into being is Paul Lauter's. ${ }^{4} \mathrm{He}$ argues that women and minority groups who were relatively prominent in the canon of the 1920 s were displaced by the professionalization of the teaching of literature. Novels in particular had been the domain of women: they were known to be avid readers and had been damned as "scribblers" by the jealous Hawthorne. Women's clubs and gatherings devoted to literary discussion had abounded, the most philosophical undoubtedly being Margaret Fuller's "Conversations" which was until recently eclipsed by Emerson and his Godlike eye. After the First World War, America, having saved the Old World from annihilation, felt obliged to prove it was not a poor cousin where culture and literature were concerned. This could only be achieved by placing the world's saviours in a position where they could accomplish such a task -even while authenticating it. White males, preferably WASPs, were accordingly appointed to cast and make known America's cultural heritage and tradition -to be understood in terms defined by Raymond Williams as the "hegemonic sense of tradition [which] is always the most active: a deliberately selective and connecting process which offers a historical and cultural ratification of a contemporary order."

The task was made easier by the development of an aesthetic theory -the New Criticism- which privileged the text by divorcing it from the intention, emotion, context and sense of continuity which had inspired it. Thus the manufacturers of literary taste could more readily project their own values at the expense of the growing consciousness of racial and ethnic communities. Of course, continuity was never entirely rejected; a "usable past" had to be found, and Perry Miller's work was largely 
responsible for establishing the Puritans in the place of honour as founders of American culture. ${ }^{6}$ Other groups -native Indians, Spanish, French, English explorers and merchants, together with other religious exiles- were dismissed as insignificant. So were women -who, after all, had no hand in the fashioning of America.

The newly established arbiters found it to their advantage to organize the canon into periods or themes, ignoring those that did not respond to their vision of reality: so, to give just one example, a host of left-wing writers were undervalued, and virtually relegated, for many decades -among them Upton Sinclair, Sinclair Lewis, Theodore Dreiser and Tillie Olsen. A carefully censored -though often, it must be admitted, an unconsciously censored- image of America was firmly established in the worlds of publishing and Academy; and the machinery to promote and perpetuate it was set in motion.

Since the 1960 s the new feminism has been dismantling this structure, saving America and its enthusiastic students from an excessively narrow vision of its own reality. And in recent years some feminist scholars have more and more felt the need of a cohesive theory which would account for all that has been achieved and provide a method for further research, thus squarely placing feminist criticism within the framework of modern critical theory. Others dispute this need. Elaine Showalter argues firmly that feminist criticism is a unique phenomenon which neither has nor needs a "Mother of Feminist Criticism"; thus it does not give rise to incestuous or murderous feelings towards our literary ancestors, as other schools do. ${ }^{7}$ Showalter, in a 1985 essay "Women's Time, Women's Space," defines feminist criticism as "rather a powerful movement than a unified theory, a community of women with a shared set of concerns but with a complex and resourceful variety of methodological practices and theoretical affiliations." She sees Anglo-American feminist criticism as distinct from the French which Alice Jardine has styled as "gynesis" and which Showalter summarily defines as the "exploration of the textual consequences and representations of sexual difference." Her own term for the Anglo-American focus is "gynocritics" which relates to the "specificity of women's writing." ${ }^{8}$ Whatever stance we adopt towards the lack of theory, however, feminist criticism has undoubtedly filled the void which Tzvetan Todorov pinpointed when he defined current trends in American literary theory. $\mathrm{He}$ identified -this was in the already distant days of 1985- two post-1968 schools of criticism:

The first of the two sorts -it is also the more dogmatic and the more sophisticated-is known as deconstruction: with some simplification, it might be described as making the question about what a text means obsolete by invariably furnishing the answer: "Nothing." The second kind, more amusing but also more naive, sometimes called pragmaticism by its advocates, renders the question pointless by answering: "Anything."

Other critics, unless they wish to risk repeating ad nauseam the same platitudes on Hawthorne and Melville, are also aware that academe requires continuous revaluation: they have had the courage to admit not only the potential of feminist criticism but also to recognize its achievements. Jonathan Culler, for example, has carefully written in On Deconstruction that feminist criticism has "had a greater effect on the literary canon than any other critical movement and has arguably been one of the most powerful forces of renovation in contemporary criticism."10

We have seen how the "forgers" of the American tradition, led by a self-laudatory yet defensive impulse, attempted to force the "widely dispersed events of our literary 
history into a single container."11 The results were predictable: in 1960 the canon of American literature showed a white man's world, a world where any worthwhile experience is, to quote Nina Baym, "inherently male."12 Since then, women in universities throughout America have fought to open up the canon. They have researched lost writers, made critical and aesthetic judgements about which texts should be incorporated into the canon, convinced publishers to reprint them, and risked their career prospects by insisting that these authors be taught. Thanks to these researchers we are now familiar with the work of Kate Chopin, Willa Cather, Charlotte Perkins Gilman; Edith Wharton is no longer mentioned merely as an aside to Henry James but has become a favorite among students.

We are also far more conscious of the breadth of American experience; we recognize, for example, that slave narratives are as much a part of American literature as Puritan captivity narratives. Tony Morrison and Alice Walker have been accorded a secure place in the canon, and Walker herself has recovered Zora Neale Hurston. Much more can still be done. I am myself researching a writer who is unknown to many academics working in Women's Studies -even in America.

Susan Glaspell (1876-1948) was born in the Midwest, became a reporter and short story writer, went to college at a time when most girls did not, wrote novels, cofounded the Provincetown Players, wrote, produced and acted in numerous plays, won a Pulitzer prize, and was Director of the Midwest Federal Theatre Project -sufficient accomplishments, one might have thought, to have her name remembered. There is no time today to study her career in detail: I will limit myself to Glaspell the playwright and to one play, and I hope that this will be enough to draw attention to her work and to her particular reading of America.

Susan Glaspell's plays, together with those of Eugene O'Neill, were "the first American plays that belonged to dramatic literature and not to the false and tawdry artifice of the uncreative theatre," wrote the drama critic Ludwig Lewisohn in the early $1930 \mathrm{~s} .{ }^{13}$ Throughout her career as a playwright, in fact, her work was held to be on a par with O'Neill's; and many other contemporary critics had no hesitation in comparing her favourably with Ibsen, Strindberg, Maeterlinck and Shaw. When staged in London, her plays earned notices that were every bit as enthusiastic as their American counterparts. James Agate, the most prestigious and influential critic of the day, ranked her play Inheritors (1920) with Ibsen's The Master Builder: he acclaimed it as "the finest achievement of the American theatre."14 If contemporary critics immediately classed Glaspell with O'Neill, more recent commentators on theatre history readily drawn the same conclusion. Professor C. W. E. Bigsby, for example, writes in his Critical Introduction to Twentieth Century American Drama (1982): "Besides Eugene O'Neill, the Provincetown Players produced one major talent in Susan Glaspell. Her work is in many ways more controlled than O'Neill's."15

Whilst O'Neill's life and work have been given full weight, however, no critic or literary historian has yet provided a full assessment of Glaspell's career and accomplishments -and of her influence on writers including O'Neill. The inevitable question is: Why? I could suggest a number of reasons that have nothing to do with the inherent or enduring value of her plays: but I believe that the very nature of Glaspell's theatrical experiments, and even her subject matter, did in fact influence her loss of popularity. I don't want to go into this in depth now as I have written on the subject elsewhere, but I will just say that Glaspell always wrote with the stage as a concrete acting space in mind and that she belonged to a circle of radicals, the New Bohemians, 
who were intensely interested in all European artistic and political innovative movements. Germany in particular was a source of inspiration and it was a play by Glaspell that was the first in America to be described as "expressionistic" by American drama critics. ${ }^{16}$ The urge to experiment of course appealed only to a certain type of audience -as did Glaspell's subject matter. In her plays, as in her novels, she questioned the established patriarchal order and examined the consequences of going against it.

Now to the play. The Verge (1921) is Glaspell's most provocative work. ${ }^{17}$ As the title suggests, it is about reaching a limit, of attempting to go beyond life and death, good and evil. It was one of the very first plays by an American to exploit European innovations in dramaturgy: it uses expressionistic settings to reveal the mind of the protagonist. As for its subject matter, the play criticizes the stifling doll's house that a marriage can become.

The play opens in a luscious and over-heated greenhouse where the protagonist Claire (who is reminiscent of E. T. A. Hoffmans's characters in her obsessiveness) experiments with plants. ${ }^{18}$ She believes she can exploit a technique of transplanting in order to create wholly new organisms which will be liberated from the previous forms and functions of plant life. Tom, Dick and Harry (confidant, lover and husband) violate her sanctum when they seek out a warm spot for breakfast. Hoping to end the farcical bickering that follows, Claire tries to express in words her Nietzschean desire to overcome established patterns and break through into whatever lies beyond; but of the three men in her life only Tom gropes towards an understanding of her hectic and disjointed mode of speech.

In Act III, Claire's sister Adelaide invades her study, a strangely twisted and uncannily lit tower which is an outward sign of Claire's highly agitated mind. Adelaide's mission is to convince her sister to play dutiful mother and wife, but Claire is too close to transcendence to heed her. Since she is about to uncover her latest experiment, the plant she calls "Breath of Life," she is staggered by fear of the retaliation of the God whose life-giving powers she has appropriated. She seeks a haven in her relationship with the sympathetic Tom, but in deference to her superior spirit he denies her that ordinary human refuge, whereupon the second act ends with Claire's hysterical plea for "Anything -everything- that will let me be nothing!" (p. 92).

In Act III, back in the greenhouse, Claire unveils her new plant -her hitherto unknown form of life. Yet the achievement is clearly ambivalent: any organism is condemned to repetition and stagnation unless it continually outreaches itself. Claire is so fully conscious of that baleful dilemma that when Tom finally offers her his love she is appalled at the prospect of being engulfed by an unchangingly mediocre way of life and chokes him to death. The murder parallels the suffocating norms of society which inevitably silence the creative urge of the non-conformist, but Claire's family see her convulsive action as the very proof of her insanity. The play ends on a savagely ironic note as Claire chants the hymn, "Nearer, my God, to Thee" -a hymn which her sister, intuiting blasphemy, had previously refused to sing in her presence. Claire, a female Faust, has become her own God and cannot be contained by societal structures and compunctions: she has broken out and is existentially free, alone in the transcendental beyond. She not only rejects the laws of the patriarchal world but refuses to deal with them on their own terms.

Glaspell lavishes no generosity on her male characters in The Verge: she allows each in turn to prove his inferiority to Claire. Tom, Dick and Harry, as their names 
suggest, are stereotypes; they are incapable of helping Claire define herself fully in a patriarchal society or of protecting her from the consequences of defying and transcending it. The male protagonists of Glaspell's earlier plays are not quite so dimwitted or paternalistic; they are simply motivated by more material concerns and recognize that there is something selfish in wanting "to be just what you want to be."19

Claire is selfish -a male prerogative in the 1920s just as it is today-and it is precisely her determination to create for herself a satisfactory vision of life that aroused the fervent admiration of the Greenwich Village feminists and reportedly brought to their voices a kind of "religious excitement" when they spoke of The Verge. 20

I have here merely touched on the elements of The Verge that contribute towards making it into a play whose values still hold today. History has not fossilized Claire's anguished struggle to achieve freedom and transcend social boundaries. We are still surrounded by stereotypes whose mediocrities will tie us to established norms in fear of the unknown. If we prefer to ignore plays like Glaspell's, it is only because we too are afraid where she, and others like her, may lead us.

\section{Notes}

1. Tillie Olsen, "One But of Twelve: Writers Who Are Women In Our Century,"in Silences (London: Virago, 1985), p. 25.

2. William Faulkner's As I Lay Dying (1930), Nella Larsen's Quicksands (1928; rpt. by Rutgers University Press, 1986), and Tillie Olsen's Yonondio begun in 1932 but not finished till five years of each other, but the threc novels deal with completely different aspects of America.

3. Adrienne Rich, "When We Dead Awaken: Writing as Re-vision," in On Lies, Secrets and Silence: Selected Prose 1966-1978 (New York: W. W. Norton, 1979), p. 35.

4. Paul Lauter, "Race and Gender in the Shaping of the American Literary Canon: A Case Study from the Twenties," Feminist Studies, 9, 3 (Fall 1983), 434-63.

5. Raymond Williams, Marxism and Literature (Oxford: OUP, 1977), p. 116.

6. The term was coined by Van Wyck Brooks in "On Creating a Usable Past," Dial 64 (11 April 1918). The Puritan tradition had been used by critics before Perry Miller -as by Mencken who blamed them for all America's ills, and More and Babbitt for whom the Puritans were the foundation of all American virtues- but no attempt had been made to come to a thorough understanding of Puritan thought.

7. For example Harold Bloom in The Anxiety of Influence (Oxford: OUP, 1973).

8. Elaine Schowalter, "Women's Time, Women's Space: Writing the History of Feminist Criticism," in Shari Benstock, ed., Feminist Issues in Literary Scholarship (Bloomington: Indiana University Press, 1987), pp. 31 and 37.

9. Tzvetan Todorov, "All Against Humanity," Times Literary Supplement (4 Oclobcr 1985), p. 1093.

10. Jonathan Culler, On Deconstruction: Theory and Criticism after Structuralism (London: Routledge \& Kegan Paul, 1983), p. 30.

11. Frank Lentricchia, After the New Criticism (Chicago: Chicago University Press, 1980), p. 203.

12. Nina Baym, "Melodramas of Beset Manhood: How Theories of American Fiction Exclude Women Authors," in Elaine Showalter, ed., The New Feminist Criticism: Essays on Women, Literature, and Theory (New York: Pantheon Books, 1985), pp. 70-71.

13. Ludwig Lewisohn, Expression in America (New York, 1932), p. 243.

p. 4.

14. James Agate, "The Dramatic World: Susan Glaspell Again," Sunday Times (24 August 1924),

15. C. W. E. Bigsby, Critical Introduction to Twentieth Century American Drama. Volume I: 19001940 (Cambridge: Cambridge University Press, 1982), p. 25.

16. Kenneth Macgowan, "The New Play," New York Evening Globe (15 November 1921). 
17. The Verge was first performed at the Playwrights' Theatre by the Provincetown Players on November 14th., 1921. It has recently been reprinted by Cambridge University Press, C. W. E. Bigsby, cd., Plays By Susan Glaspell (1987).

18. In Act I Claire sings "Oh night of love," from Offenbach's opera Tales of Hoffmann, based on "The Sandman" (Act I), and "Councillor Krespel" (Act II), both tales of obsession and fear. E. T. A. Hoffmann, Tales of Hoffmann (Harmondsworth: Penguin, 1982).

19. Susan Glaspell, Inheritors, ed. by C. W. E. Bigsby (Cambridge University Press, 1987), p. 136. 20. Hutchins Hapgood, A Victorian in the Modern World (1939; Seattle \& London: University of Washington Press, 1972), p. 377. 